Annals of Warsaw University of Life Sciences - SGGW

Land Reclamation No 44 (1), 2012: 25-33

(Ann. Warsaw Univ. of Life Sci. - SGGW, Land Reclam. 44 (1), 2012)

\title{
Application of the Bayesian Belief Nets in dam safety monitoring
}

\author{
DOROTA MIROSŁAW-ŚWIĄTEK ${ }^{1)}$, MARIUSZ KEMBŁOWSKI, \\ WŁADYSŁAW JANKOWSKI ${ }^{2)}$ \\ 1) Department of Hydraulic Engineering, Warsaw University of Life Sciences - SGGW \\ ${ }^{2)}$ Institute of Meteorology and Water Management, Warsaw
}

\begin{abstract}
Application of the Bayesian Belief Nets in dam safety monitoring. The systems for earth dam monitoring should enable measurements of basic physical parameters describing the behavior of the structure, including: soil water pressure, soil stress, displacements, leaks, and drainage discharges. In the case of earth dam safety assessment, the monitoring data are used to detect any anomalies in dam behavior. In this paper, the dam safety has been analyzed using the Bayesian Nets. Two types of information: water pressure measurements and drainage discharge measurements are used in analyses. The seepage anomalies in the Klimkówka Dam were considered in demonstrate the practical advantages of using the Bayesian Nets for monitoring data interpretation. Presented examples of the Bayesian Nets applications (forward and backward propagation) in analysis of seepage through earth dams show that this method can be an effective tool supporting an assessment of dams technical condition and monitoring of the dam safety.
\end{abstract}

Key words: Bayesian Nets, dam safety, dam monitoring.

\section{INTRODUCTION}

In this paper, we consider the interplay among engineering monitoring, modeling, and management $\left(\mathrm{Em}^{3}\right)$, with particular emphasis on dam safety. The engineering community has been working on dam safety assessment for many decades. The physical/mechanical and chemical principles of the relevant processes have been described in the litera- ture, and are reasonably well understood. One could argue that there is always room for improvement in our understanding, and we do not disagree with this argument. Our professional experience tells us, however, that while the principles are well understood, the practical applications of such to the problem of dam monitoring and safety are frequently flawed and characterized by the lack of rigorous methodology for dam its monitoring and safety assessment (Vick 2000; Jeon et al. 2009). In particular, we have often encountered the following problems:

1. Monitoring by checklist. Most of the time, the one-size-fits-all philosophy is used, i.e. the assessment monitoring parameters do not reflect specific site features, and there is no clear connection between monitoring design and specific geo-hydro-chemical conditions.

2. Engineering by Rules of Thumb. These Rules of Thumb are clearly easy to enforce and report, but there is no mechanism, or effort, to demonstrate that their fulfillment will actually effectively help in reaching the safety objectives.

3. Lack of clear decision framework. It is very seldom that we see an effort to anticipate the decision pathways based on the future monitoring in- 
formation, and its use in dam safety diagnosis. The typical practice is that data is first collected, and then one tries to figure out what to do with it.

4. Lack of a coherent data analysis/evaluation framework. Even the collected data are not properly analyzed and/or visualized, since it is generally not known how, and particularly why to use it.

5. Lack of meta-modeling framework. Various models are used to simulate the mechanical, hydrologic phenomena in dams without explicit, or even implicit, consideration given to the true modeling objectives. Furthermore, the model choice is more often based on its availability or familiarity rather than on the project objectives.

6. Lack of methodology for assessing the value of information. Hence there is no clear way to choose among various monitoring scenarios/systems.

As a result of these problems, in the realm of $\mathrm{Em}^{3}$, we are faced with a considerable waste of resources. We believe that there is a strong need for a framework that would enable us to address simultaneously the following questions:

- Why, what, where, when (the four w's), and how to monitor it?

- What models to use?

- When are sufficient data for decisionmaking available in the context of the engineering, safety objectives and site specifics?

- How does one estimate the value of information?

- What consistent methodology could be utilized to utilize any new monitoring information in assessing dam technical conditions and state?
- How to design efficient systems for monitoring dam safety?

In the case of earth dam safety assessment, the monitoring data are used to detect any anomalies in dam behavior. The data could be, and are, analyzed using a variety of methods. Frequently these methods are limited to either deterministic models, or simple regression. However, we observe that the safety assessment procedure is intrinsically probabilistic, since the expert knowledge used in the assessment, as well as the data utilized in the procedure, are characterized by some, often high, degree of uncertainty. Such assessment belongs to a larger class of problems known in the AI literature as "probabilistic reasoning". Experimental statistics demonstrates that human brain is not particularly well suited to processing uncertain data mutually interconnected via probabilistic relationships. We thus seek assistance form a more rigorous procedure, namely Bayesian Belief Nets (BBNs) (Russel and Norvig 1995). In short, BBNs are a tool for propagating new findings in a net of nodes (in general, random quantities) connected via probabilistic links (in general, conditional probabilities).

\section{EARTH DAM MONITORING}

The systems for earth dam monitoring should enable measurements of basic physical parameters describing the behavior of the structure, including: soil water pressure, soil stress, displacements, leaks, and drainage discharges. To monitor these quantities the following devices are frequently used: piezometers, tensiometers, dynamometers, flumes, etc. In 
this paper we will consider only some of these measurements, our purpose being to demonstrate how the proposed methodology works in general. Site-specific applications will require a careful consideration of multiple sources of information, and the interaction among various types of information.

For the illustration purposes we have selected two types of information: 1) water pressure measurements using piezometers, and 2) drainage discharge measurements using discharge flumes.

To illustrate the proposed methodology, we consider the problem of seepage through an earth dam. In the dam depicted in Figure 1 there are two structural elements lengthening the seepage route and thus contributing to the dam safety. These elements are: 1) a concrete screen on the upstream slope of the dam, and 2) a clay reservoir seal (known as blanket) connected to the screen. This type of anti-seepage solution has been used, for example in the Chańcza Dam (Mirosław-Świątek et al. 2009). The seepage behavior is monitored by two sets of piezometers, one on the upstream side of the dam (P1), and one on its downstream side (P2). In this case, the principal cause of water table rise in $\mathrm{P} 1$ and/or P2 could be structural damage in the anti-seepage structures, either the concrete screen or the clay seal. This simple scenario could be summarized in the form of BBN depicted in Figure 2. The structural element nodes (in the lingo of the BBNs, parent nodes) have two states each, namely either the element is damaged (state $=\mathrm{T}$ ) or not (state $=F)$. In the tables next to the nodes related to the structural elements we show the a priori probabilities of their damage. Next to the observation nodes (called child nodes) we show the conditional probabilities of water level rise in the piezometers, conditioned on the state of the structural elements. The entries in the tables are typically estimated based on the expert knowledge.

Such Bayesian Net enables one to address a set of simple questions: what is the probability of water table rise in $P$ based on the state of each of the structural elements. This type of reasoning is called forward propagation, and could be readily performed using Monte-Carlo simulations (Korb 1995). A much more interesting us of the Bayesian Nets is the

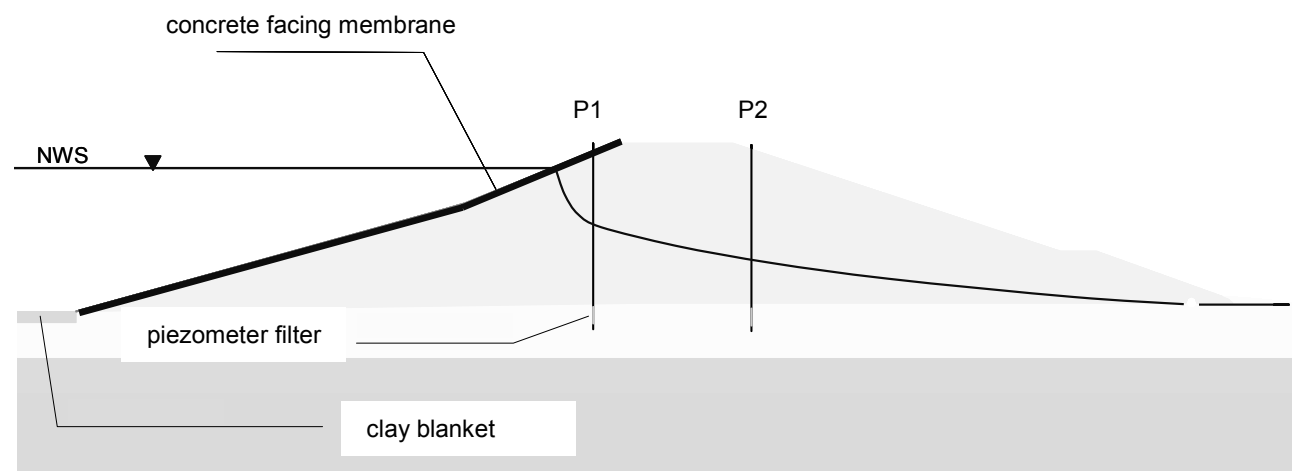

FIGURE 1. Example of earth dam with sealing element (concrete membrane, clay blanket) and piezometers (P1, P2) monitoring water level in dams shell (NWS - normal water surface) 


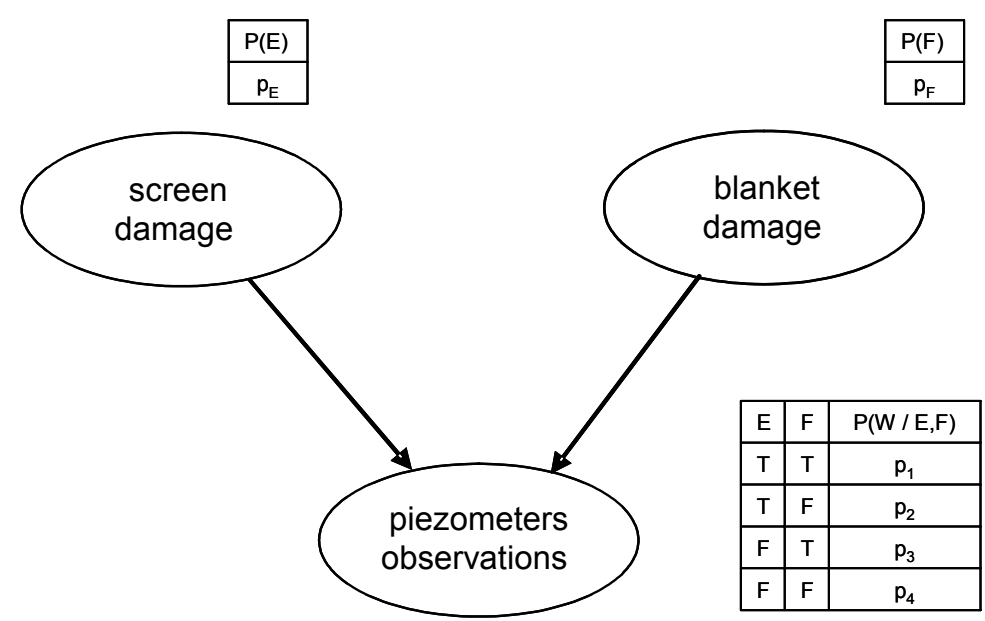

FIGURE 2. Example of Bayesian Net in earth dam monitoring. Letters E, F, W mean following events "screen damage", "blanket damage", "increase of piezometers observations"

backward propagation of the findings. The relevant question is: what is the a posteriori probability of element damage given the piezometer observations. For the net depicted in Figure 2, such estimation of a posteriori probabilities could be readily accomplished by a direct use of Bayes' rule. However the computation becomes significantly more involved when there are a number of interconnected parent and child nodes (Cooper 1990). In such situations it is necessary to use the computer BBN software, either free for relatively simple problems (with a limited number of nodes), or commercial, for more complex nets.

To demonstrate the practical advantages of using the Bayesian for monitoring data interpretation, we consider the seepage anomalies in the Klimkówka Dam (Florkowski 2005).

The Klimkówka Dam is an earthen structure with a clay core located above an anti-seepage cement screen. The Dam is located on Ropa River, km 54+400. The dam is equipped with a drainage system that consists of clay core protective drain, and a horizontal main drainage. The seepage phenomena are monitored via a set of upstream (UP) and downstream (DW) piezometers (Fig. 3). In addition the drainage discharge rates (DR) are also monitored.

For the sake of simplicity, let us assume that the external factors, such as rainfall or the reservoir water level fluctuations have negligible impact on the monitored seepage quantities. In this case any "abnormal" functioning of the structure could be observed as the rise or lowering of the water level in piezometers (UP or DW), or an increase or decrease in the drainage discharge rates (DR). The potential causes of such anomalies are: leaks through the cement screen or clay core, or the malfunctioning (namely plugging) of the drainage system. These three potential causes result in different responses in the upstream (UP) and downstream (DS) piezometers. Thus in the following we will consider these two piezometer groups separately. Each group has two states: 


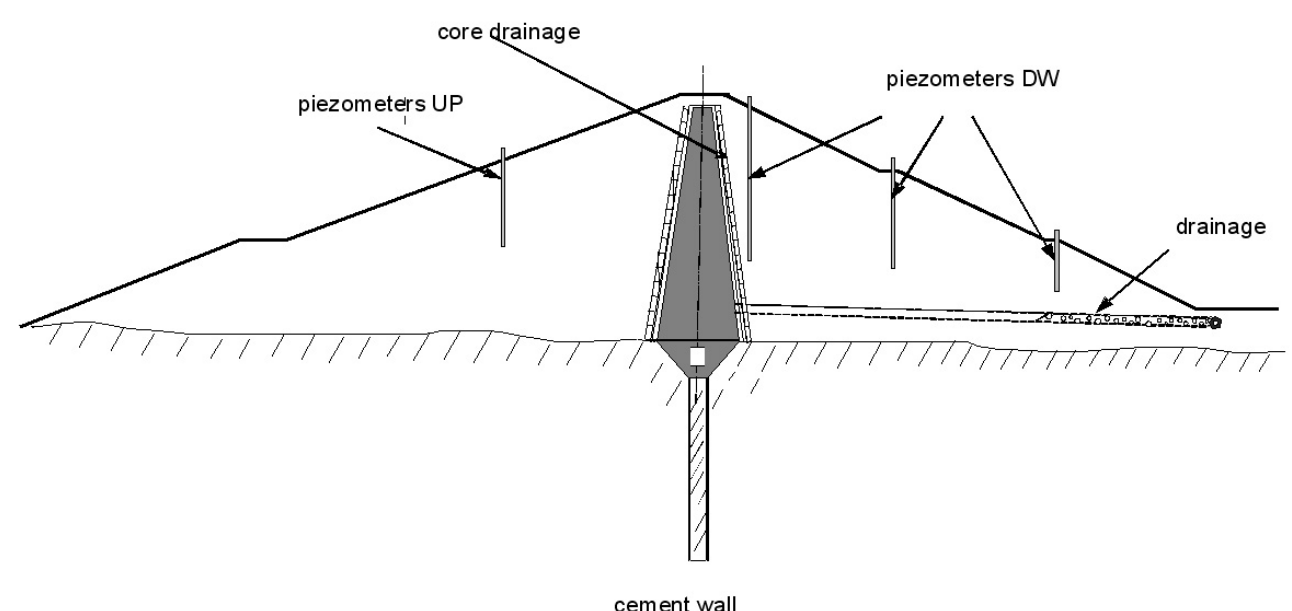

FIGURE 3. Klimkówka Dam cross-section with sealing, drainage elements and piezometers monitoring of water level in the dam

1) rise, and 2) lowering of the WL. The the clay core as A2. Finally, A3 denotes increase of WL in US is denoted as B1, in malfunctioning of the drainage system. DS as B2. Similarly, the lowering is de- Figures 4, 5, and 6 show partial Bayenoted as $\sim \mathrm{B} 1$ and $\sim \mathrm{B} 2$. sian Nets, including the links between

The increase in the drainage discharge is denoted as B3, its decrease as $\sim$ B3. Leaks through the cement screen, caused by the damage to its integrity, are denoted as A1, whereas leaks through potential causes of abnormal observations (A1, A2, A3) and the monitored quantities (B1, B2, B3). Next to the observation nodes we show the Conditional Probability Tables (CPTs). These tables,

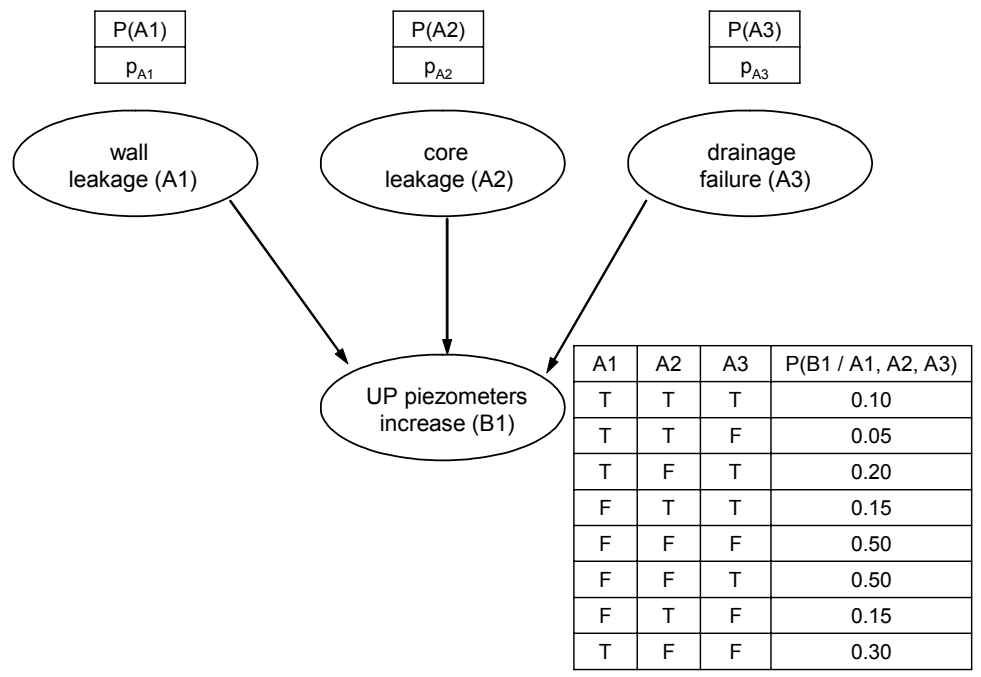

FIGURE 4. Bayesian Net - events A1, A2, A3, B1 


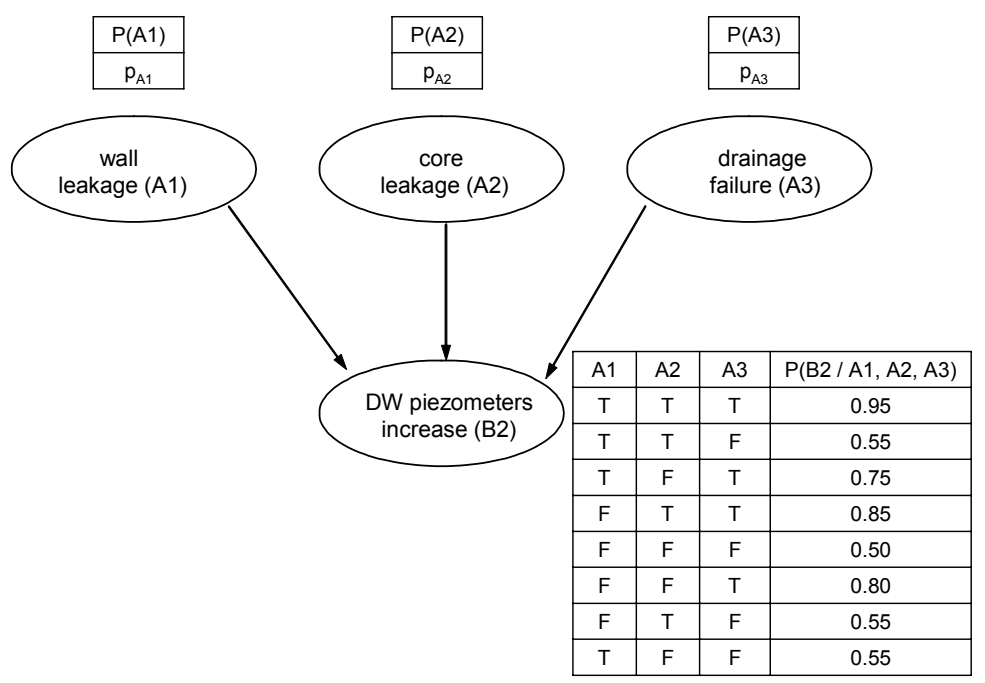

FIGURE 5. Bayesian Net - events A1, A2, A3, B2

in addition to the overall network struc- state are equally likely. Based on this ture, are the principal contribution of the a priori information and the CPTs we can expert knowledge.

We initially assume that the $a$ priori probabilities of $\mathrm{A} 1, \mathrm{~A} 2$, and $\mathrm{A} 3$ are equal to 0.5 . This implies the highest information entropy, i.e. the information is highly disorganized, and each cause and now perform the forward propagation of information to estimate the probabilities of the reactions of monitored quantities (Fig. 7). The results show that the most likely response will be the lowering of the WL in US $(\sim B 1)$, with $p=0.75$. The

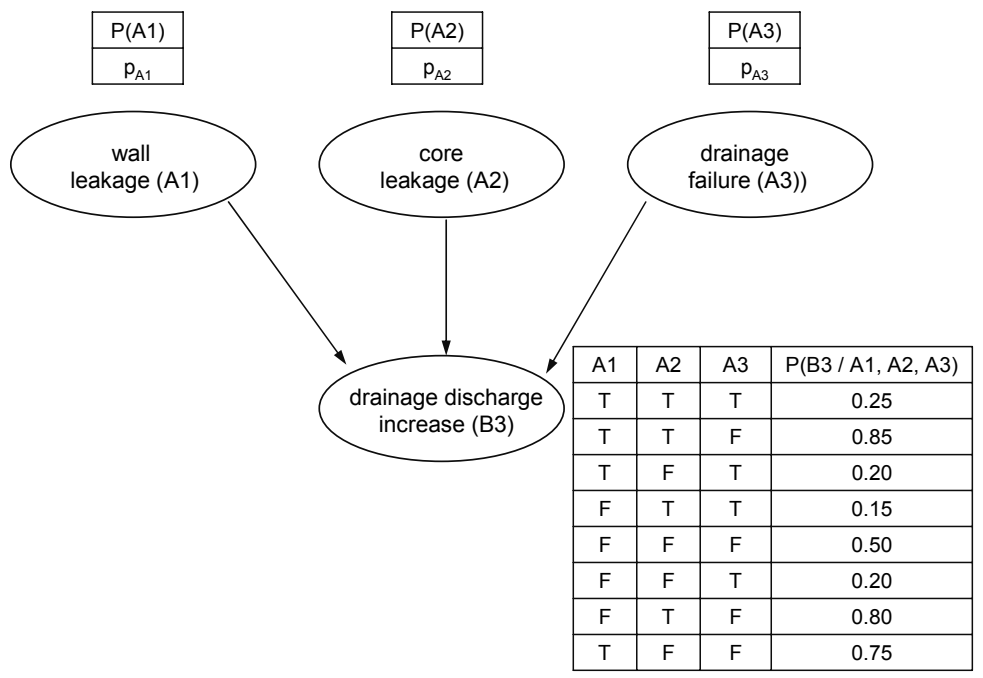

FIGURE 6. Bayesian Net - events A1, A2, A3, and B3 
probability of B2 (rise of WL in DS) is the $p=0.69$. The probabilities of increase and decrease of DR are 0.46 and 0.54 , respectively.

If we next assume that $\mathrm{p}_{\sim \mathrm{A} 1}=\mathrm{p}_{\sim \mathrm{A} 2}=$ $=\mathrm{p}_{\sim \mathrm{A} 3}=100 \%$ (Fig. 8), the forward propagation shows that all reaction states are equally probable. This propagation constitutes a test for the proper behavior of our net. The result indicates that the BBN performs according to our expert knowledge; if there is no cause for abnormalities present, the increase and decrease in observed quantities are equally likely.

In the following simulations we investigate the effects of one of the potential causes of dam malfunctioning on the monitored parameters. The clay core damage $\left(\mathrm{p}_{\mathrm{A} 1}=0, \mathrm{p}_{\mathrm{A} 2}=100 \%, \mathrm{p}_{\mathrm{A} 3}=0\right)$, results in the lowering of WL in UP with $\mathrm{p}=0.85$, and increase in DR with $\mathrm{p}=$ $=0.8$. The malfunctioning (plugging) of the drainage system $\left(\mathrm{p}_{\mathrm{A} 1}=0, \mathrm{p}_{\mathrm{A} 2}=0\right.$, $\left.\mathrm{p}_{\mathrm{A} 3}=100 \%\right)$ results in the increase of WL in UP $(p=0.8)$, and the decrease in $\operatorname{DR}(\mathrm{p}=0.8)$.

In the next step the network was used to back-propagate the monitoring information. We would like to determine the likely cause of the decrease in DR, and increase in DS. The results (Fig. 9) show that, in agreement with our diagnostic intuition, the most probable cause is malfunctioning of the drainage system $(\mathrm{p}=82.2)$. However, if we remove the DS evidence, the probability of A3 goes down to $p=60.9$ (Fig. 10). Finally, if we consider that the WL in US goes down, the probability of A2 increases from 52.7 to 61.1 (Fig. 11).

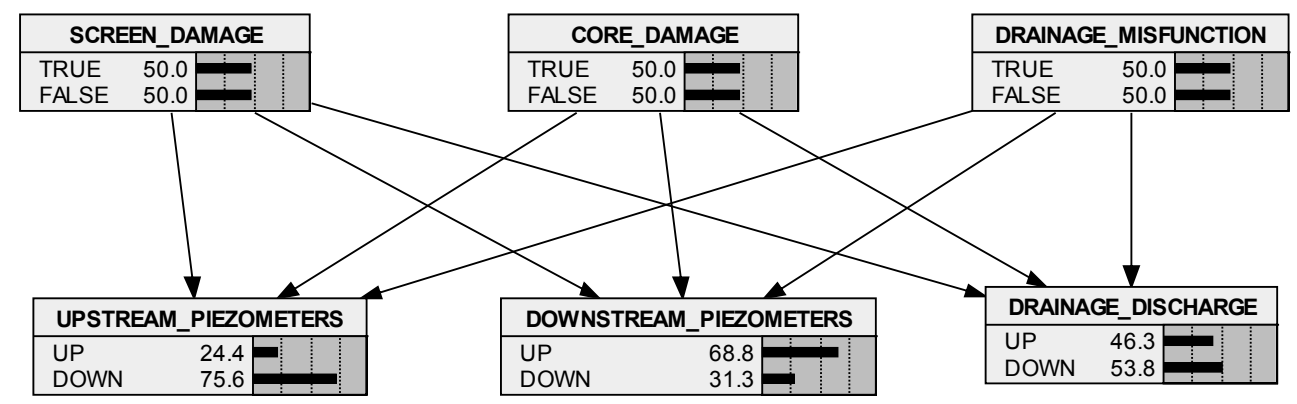

FIGURE 7. Forward propagation $-\mathrm{P}(\mathrm{A} 1)=\mathrm{P}(\mathrm{A} 2)=\mathrm{P}(\mathrm{A} 3)=0.5$

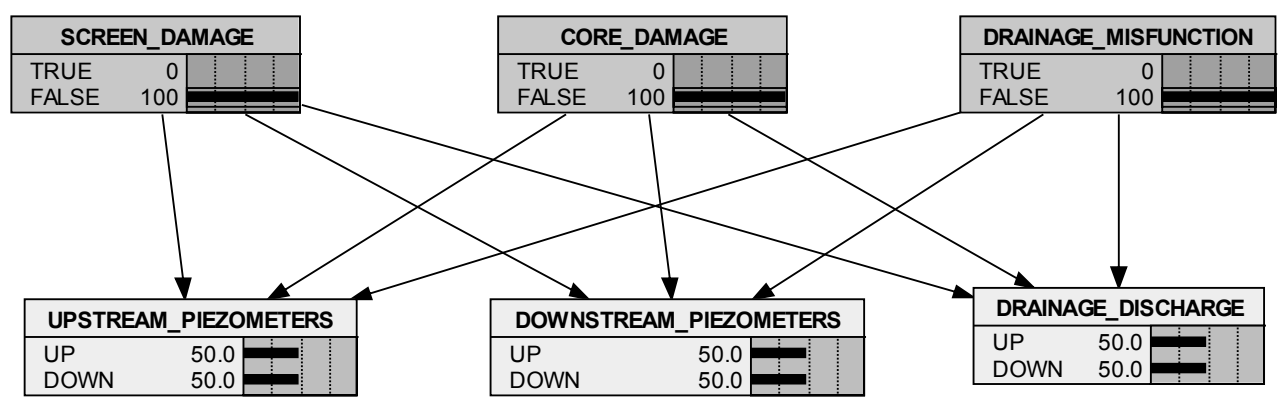

FIGURE 8. Forward propagation $-\mathrm{P}(\mathrm{A} 1)=\mathrm{P}(\mathrm{A} 2)=\mathrm{P}(\mathrm{A} 3)=0$ 


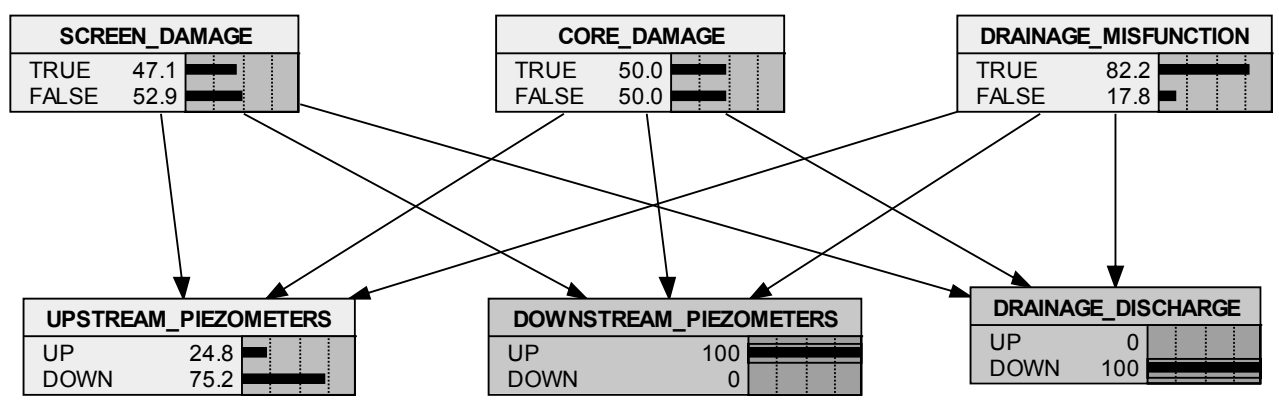

FIGURE 9. Backward propagation $-\mathrm{P}(\mathrm{B} 2)=1, \mathrm{P}(\mathrm{B} 3)=0$

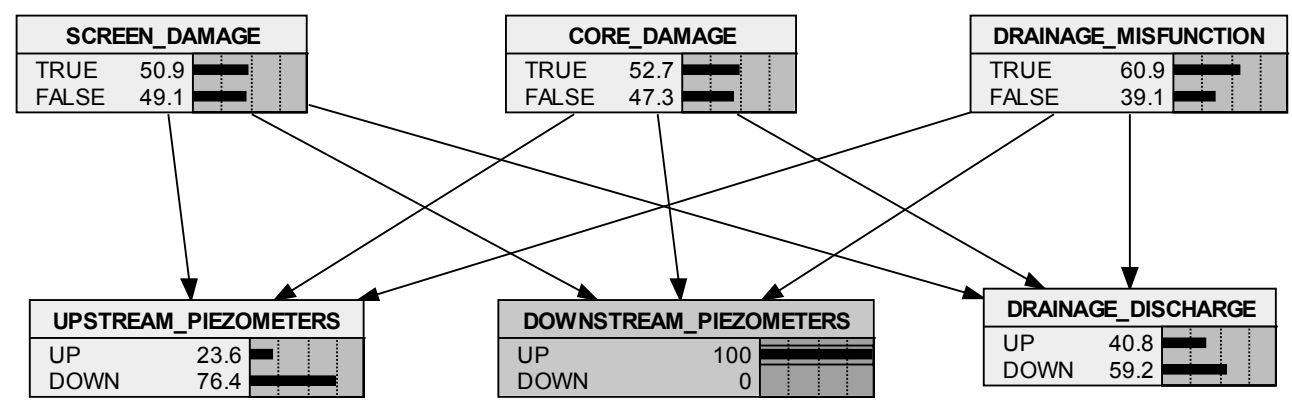

FIGURE 10. Backward propagation $-\mathrm{P}(\mathrm{B} 2)=1$

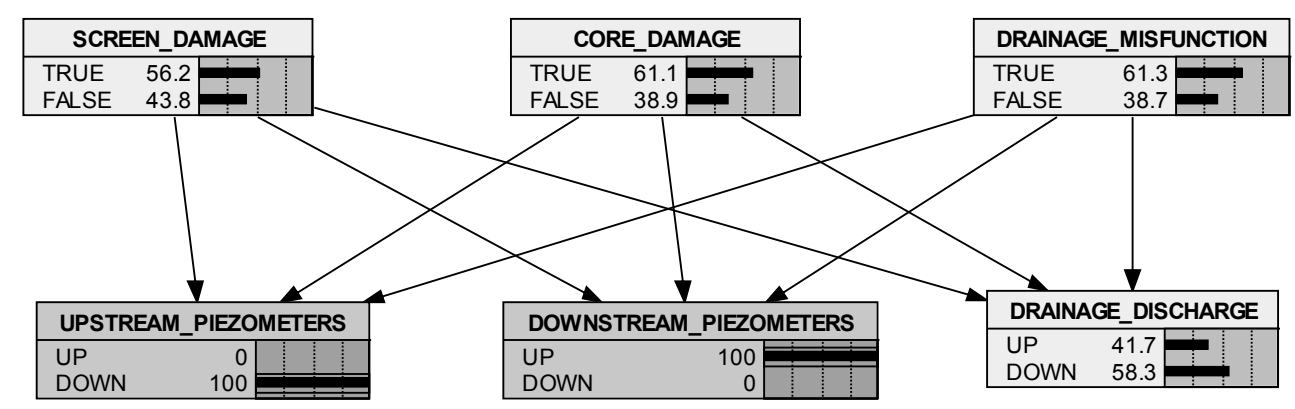

FIGURE 11. Backward propagation $-\mathrm{P}(\mathrm{B} 1)=0, \mathrm{P}(\mathrm{B} 2)=1$

\section{SUMMARY AND CONCLUSIONS}

Presented in this paper examples of the Bayesian Nets applications in analysis of seepage through earth dams show that this method can be an effective tool supporting an assessment of dams technical condition and monitoring of the dam safety. It should be emphasized that very significant factors affecting the backward evidence propagation, and thus the final system diagnosis, are the net structure (nodes and links) and the CPTs. These encapsulate the expert knowledge about the system. This knowledge is based on the experts' prior experience, and also on 
the observed, in the process of simulation exercises, system behavior.

Except for sufficient theoretical knowledge and experiences related with seepage through different types of earth dams, an expert ought to have detailed data and information on the current state of: anti-seepage and drainage structures of the dam, the ground density in the shell and the base of the dam, the permeability of the piezometers, and also data concerning the influence of water flowing down the slope on the water level in the dam body. All these data and information are required to analyze the technical condition of a dam by applying Bayesian Nets. Additionally, vital information can result from the analysis of depression curve in the dam body, in the periods of flood water flow through the spillway of the dam.

\section{REFERENCES}

FLORKOWSKI J. 2005: Zbiornik Klimkówka na Ropie ma już za sobą ponad 10 lat eksploatacji. Gosp. Wodn. (Water Management) 10.

MIROSŁAW-ŚWIĄTEK D., ZIELIŃSKA M., RZADKOWSKI B., KOSIK A. 2009: Zastosowanie numerycznego modelu filtracji do oceny wpływu dociążenia podnoża skarpy odpowietrznej pryzmą narzutu kamienno-żwirowego dla prawej strony zapory Chańcza. Gosp. Wodn. (Water Management) 12.

VICK S.G. 2000: Engineering applications of dam safety risk analysis. 20th Congress on Large Dams, ICOLD, Q76 R21, 325-335.

JEON J., LEE J., SHIN D., PARK H. 2009. Development of dam safety management system. Advances in Engineering Software, 40 (8), 554-563.
KORB K. 1995: Inductive learning and defeasible inference. Journal for Experimental and Theoretical AI, 7, 291-324.

COOPER G.F. 1990: The computational complexity of probabilistic inference using belief networks. Artificial Intelligence, 42, 393-405.

RUSSEL S., NORVIG P. 2003: Artificial Intelligence: A Modern Approach. Prentice Hall, USA.

Streszczenie: Zastosowanie sieci Bayesa w monitoringu bezpieczeństwa zapór wodnych. Systemy monitorowania zapór ziemnych powinny umożliwiać pomiar podstawowych parametrów fizycznych opisujących zachowanie się konstrukcji. Do podstawowego monitoringu należą pomiary piezometryczne, pomiar przemieszczeń, wydatki w drenażach, obserwacje przecieków. W przypadku zapór ziemnych dane $\mathrm{z}$ monitoringu stosowane są w celu wykrycia anomalii w zachowaniu się obiektu. W niniejszej pracy w ogólny sposób zaprezentowano możliwość wykorzystania sieci Bayesowskich do analizy bezpieczeństwa zapory wodnej w oparciu o monitoring piezometryczny i obserwacje wydatków w drenażu. Na przykładzie zapory Klimkówka pokazano możliwość zastosowania wnioskowania w przód i wstecz w celu poznania przyczyn nieprawidłowości w przebiegu filtracji. Omówione przykłady analizy wskazują, że sieci Bayesowskie mogą być skutecznym narzędziem wspomagającym ocenę stanu technicznego zapór.

Stowa kluczowe: siatki Bayesa, bezpieczeństwo zapór wodnych, monitoring zapór wodnych.

\section{MS. received December 2011}
Authors' addresses:
Dorota Mirosław-Świątek
Katedra Inżynierii Wodnej
Szkoła Główna Gospodarstwa Wiejskiego
ul. Nowoursynowska 166
02-787 Warszawa
Mariusz Kembłowski, Władysław Jankowski
Instytut Meteorologii i Gospodarki Wodnej
ul. Podleśna 61, 01-673 Warszawa
Poland
e-mail: dorotams@levis.sggw.pl 